\title{
EFFECT OF THROMBOPOIETIN RECEPTOR AGONISTS (ROMIPLOSTIM) ON HEPATIC THROMBOCYTOPENIA IN CIRRHOTIC MALE ALBINO RATS
}

\author{
By
Ahmed El-Sayed Nour El-Deen ${ }^{1}$,Ahmad Mahmoud Mohammed Gad- Allah $^{1}$, Ahmad Taha ${ }^{2}$, Abd El-Megeed Mansour ${ }^{3}$
${ }^{1}$ Department of Physiology, Faculty of Medicine, Al-Azhar University, Assuit, Egypt
${ }^{2}$ Department of Physiology, Faculty of Medicine Port Said University, Egypt
${ }^{3}$ Department of Physiology, Faculty of Medicine Suez University, Egypt

Correspondence to: Ahmed El-Sayed Nour El-Deen, Department of Physiology, Faculty of Medicine, Al-Azhar University, Assuit, Egypt

E-mail: drnoor83@ hotmail.com

Fax: +2-0882148119; Phone: +2-0882148103

\section{Conflict of interest:}

The authors declare that they have no competing interest.

\section{Financial support:}

This study was funded by Department of physiology, Faculty of Medicine, Al-Azhar University, Assuit, Egypt .without any particular role in the study design, recruitment of individuals, data analysis or writing of the report.

\begin{abstract}
Background: Thrombocytopenia in patients with chronic liver disease (CLD) can negatively affect the patient's carein advanced liver disease by interfering with diagnostic and therapeutic procedures. Decrease levels of thrombopoietin hormone in CLD lead to decrease rate of platelet production and maturation. Because of the short half-life of platelets repetitive platelet transfusions are not a practical solution to thrombocytopenia.

Objective: To assess the role of thrombopoietin receptor agonists (Romiplostim) in treatment of thrombocytopenia in CLD.

Material and Methods: One hundred twenty adult male albino rats were used in this study. They were divided into four groups as follows: Group (N) Normal control (20 rats) Group (C) cirrhotic control group (40 rats) Group (NR) Normal treated with Romiplostim (20 rats). Group (CR) cirrhotic treated with Romiplostim (40 rats).After sex weeks the rats of groups $\mathrm{C}$ and $\mathrm{CR}$ were divided randomly into two equal groups (CA and CB, CRA and CRB) and the rats of groups CA and CRA were fasted for 8 hours but had free access to water, and then anesthetized, and blood sample was collected for measurement of platelet count, total protein, albumin, and liver functions, and specimens from liver were fixed for histopathological examination for these groups. After eight weeks, the same producers were used for the rats of groups N, NR, $\mathrm{CB}$ and $\mathrm{CRB}$. The separated serum was used for the determination of the levels of total protein, albumin, liver functions, and all liver sections were examined using light microscope.
\end{abstract}


Results: There were significant increase of platelet count in rat groups receiving Romiplostim (NR, CRA and $\mathrm{CRB}$ ) when compared to other groups (N, CA and $\mathrm{CB}$ ) and there were significant increase in platelet count in rats received Romiplostim by time pass (CRB if compared by CRA). On the other hand, Romiplostim has insignificant effect on liver function tests in all rat groups, also showed no effect on histopathological examinations of liver sections in different rat groups (NR, CRA and CRB).

Conclusions: Romiplostim administration increase platelet count in cirrhotic albino rats.

Keywords: Thormbopiotin, Romiplostim, Cirrhosis, Thrombocytopenia.

\section{INTRODUCTION}

In patients with chronic liver disease (CLD), thrombocytopenia (platelet count $<150,000 / \mu \mathrm{L})$ is the most common hematological complication. It is assign of advanced liver disease and poor prognosis (Mitchell et al., 2016). Thrombocytopenia has been found in $75 \%$ to $86 \%$ of patients with cirrhosis. Thrombocytopenia can be affecting the care of patients with advanced liver disease by interfering with diagnostic and therapeutic approach (Afdhal et al., 2012). Factors contributing to the development of thrombocytopenia can be divided into those that cause decreased production, increased destruction and splenic sequestration (Mitchell et al., 2016). The increased destruction of platelet in cirrhosis occurs by a number of pathways; increased shear stress, bacterial translocation, increased fibrinolysis and infection, result in an increased rate of platelet aggregation. Decreased levels of thrombopoietinin CLD result in decreased rate of platelet production (Qureshi et al., 2016). Thrombopoietin hormone regulates both platelet formation and maturation. Splenic sequestration results from hypersplenism. Pathophysiology of the thrombocytopenia of CLD is complex, but it is crucial when considering correct strategies in treatment (Mitchell et al., 2016). Repetitive transfusion of platelet is not a practical solution to thrombocytopenia because platelets have short half-life and the all immunization which may be develops. The risk of complications associated with repeated transfusion also significantly increased (Gangireddy et al., 2014).

The treatment of thrombocytopenia in patients with cirrhosis has been a challenging problem for years. In the 1960s Splenorenal shunts were developed, but later stopped due to a high rate of mortality from liver failure (Vang et al., 2019). Splenectomy or partial splenectomy (PS), gained popularity because of fewer complications associated with this procedure. With advanced laparoscopic techniques, splenectomies with minimal complications have been performed since the late 1990s and better correction of thrombocytopenia when compared with PS. In the 1970s splenic embolization has been successfully done. Partial splenic embolization is gaining in popularity (Gangireddy et al., 2014). Its cloning, thrombopoietin and its receptor have been the main focus for the development of pharmacological treatment options of thrombocytopenia (Basser, 2020).

Thrombopoietin recept or agonists (TPO-R) approved for the treatment of chronic idiopathic thrombocytopenic purpura (ITP) in patients with insufficient response to at least one other therapy. TPO-R agonist increases platelet formation by binding to the 
transmembrane domain of the TPO-R. It does not compete with endogenous TPO in vitro, and it induces proliferation and differentiation of $\mathrm{BM}$ progenitor cells in the megakaryocyte lineage (Saleh et al., 2013). Most of these agents are primarily developed for treating chronic ITP, and data on their application in thrombocytopenia in chronic liver disease are limited (Ehrlich et al., 2017).

Our study aimed to assess the role of TPO-R (Romiplostim) in treatment of thrombocytopenia in CLD.

\section{MATERIALS AND METHODS}

\section{Experimental Animals:}

One hundred and twenty adult male albino rats of a local strain, 8 weeks of age and weighing from 150 to $200 \mathrm{~g}$ used in this study were obtained from The Nile Co. For Pharmaceuticals and Chemical Industries (Cairo). They were kept in suitable cages $(20 \times 32 \times 20 \mathrm{~cm}$ for every 3 rats) at room temperature, with the natural light-dark cycle at the animal laboratory of Pharmacology Department, Al- Azhar Faculty of Medicine (assuit). They were fed on the standard food prepared from commercial rat food formula (El-NasrPharmaceutical Co.) in addition to bread and green vegetables with free water supply. They were kept for ten days to adapt to the new conditions before starting the experiment.

\section{Chemicals:}

Thioacetamide (TAA) (Sigma-Aldrich Corp., St. Louis, MO, USA): It was dissolved in $0.9 \% \mathrm{NaCl}$ solution and given by intraperitoneal injection at a dose of $200 \mathrm{mg} / \mathrm{kg} \mathrm{BW}$, twice weekly for four weeks (Said et al., 2013).
Romiplostim (Amgen, Thousand Oaks, CA, USA) given by subcutaneous injection at dose of $0.3 \mathrm{mg} / \mathrm{kg}$ as a single dose (Cooper et al., 2012).

Aspartate aminotransferase (AST) and alanine amino transferase (ALT) total and direct bilirubin, total protein, albumin, alkaline phosphatase, and $\gamma$ - glutamyl transpeptidase Kits Sigma-Aldrich Chemie GmbH (Liu et al., 2018). These tests were carried out using Integra 400 auto analyzer (Roche diagnostics Inc., Indiana, Indianapolis, USA).

Platelet count: It was carried out using Sysmex automated hematology analyzer (SysmexInc, Kobe, Japan).

\section{Study design:}

\section{A. The animal was divided into four groups as follows:}

Group (N): Normal control (20 rats) were served as controls and intraperitoneally injected with saline solution $(0.9 \% \mathrm{NaCl})$ twice weekly throughout the course of the experimental period.

Group (C): Cirrhotic control group (40 rats). Were given $200 \mathrm{mg} / \mathrm{kg}$ body weight of TAA. By intraperitoneal injection, twice weekly for four successive weeks.

Group (NR): Normal treated with Romiplostim (20 rats) were given Romiplostim subcutaneous injection at dose of $0.3 \mathrm{mg} / \mathrm{kg}$ as single dose

Group (CR): Rats (40 rats) were intraperitoneally injected with TAA at the same dose given to group $\mathrm{C}$ and then given Romiplostim by subcutaneous injection at dose of $0.3 \mathrm{mg} / \mathrm{kg}$ as single dose at 5 th week. 


\section{B. The study was divided into two steps:}

Step 1: Assessment of liver injury and platelet count before administration of Romiplostim: After four weeks, the rats of groups $\mathrm{C}$ and $\mathrm{CR}$ were divided randomly into two equal groups (CA and $\mathrm{CB}, \mathrm{CRA}$ and $\mathrm{CRB}$ ) and the rats of groups $\mathrm{CA}$ and CRA were fasted for $8 \mathrm{~h}$ but had free access to water, and then anesthetized with diethyl ether. Incisions were made into the ribs with a sterile pair of scissors to expose the heart. A sterile syringe with needle was used for collection of blood directly from the heart of each of the rats, by cardiac puncture. The blood sample was divided into two separate the large one were centrifuged at $5000 \mathrm{rpm}$ for 10 min, and the clear samples of blood serum were separated and stored at $-80 \mathrm{C} 0$ until used for the determination of liver functions, total protein and albumin, and the rest of the blood samples were analyzed using an automated machine using the standard procedure for blood analysis (KX-21 haematological analyzer made by Symex Kobe Japan) for measurement of platelet count. Abdomen of the animals were opened and apecimens from liver were fixed immediately in $10 \%$ neutral buffered formalin, embedded in paraffin, prepared as 5 - $\mu \mathrm{m}$-thick sections, and stained with hematoxylin and eosin (HE) to assess the histopathological examination for these groups (Bancroft et al., 2019).

Step 2: Assessment of liver injury and platelet count after administration of
Romiplostim: After eight weeks, the same producers used for the rats of groups $\mathrm{N}$, $\mathrm{NR}, \mathrm{CB}$ and CRB. Measurement of platelet was done and the separated serum was aliquotted and stored frozen in epindorffs tube at $-80^{\circ} \mathrm{C}$ until used for the determination of the levels of total protein, albumin, alanine aminotransferase (ALT), aspartate aminotransferase (AST), alkaline phosphatase (ALP), $\gamma$ glutamyltranspeptidase, total bilirubin and direct bilirubin. The method of Reitman and Frankel was used to determine the levels of serum ALT and AST (Reitman and Frankel, 2014). The method of Szasz was used to measure the level of serum ALP (G Szasz, 2019).Serum level of total bilirubin and direct bilirubin was estimated using the method of Lubran (Lubran, 2019). All liver sections were examined using light microscope (Olympus BX61 - USA) connected to motorized controller unit (Olympus bxucb - USA) and photographed by a camera (Olympus DP72 - USA).

C-Statistical Methods: Data were analyzed using the statistical package for the social sciences (SPSS) for Windows, version 22 (SPSS Inc., Chicago, Illinois, USA).

- Qualitative data were expressed as frequency and percentage.

- Quantitative data were presented as mean \pm standard deviation (SD), and range. 


\section{RESULTS}

A. Effect of Romiplostim on platelet count in different rat groups:

The platelet count in NR group (267.05) was significantly elevated compared to other groups, followed by the $\mathrm{N}$ group (247.15). The CRB group gave higher significantly platelet value (215.55) than CRA group (161.55). The lowest platelet value was CA (89.6) and CB (83.65) groups with an insignificant difference as shown in table (1).
There was a decrease in the Platelet of rats in CA, CRA, CB, and CRB compared to the $\mathrm{N}$ control group, with a range of $13 \%$ to- $64 \%$, whereas the NR group increased by $9 \%$ (Figure 1).

Figure (2) Showed Percentage of platelet for CA, CRA and CRB groups compared to $(\mathrm{CB})$ group. The increment in percentage was CRB (158\%), CRA $(93 \%)$ and $\mathrm{CA}(7 \%)$ compared to $\mathrm{CB}$ group.

Table (1): Effect of Romiplostim on platelet count of different rat groups

\begin{tabular}{|c|c|}
\hline Groups & Platelet \\
\hline CA & $89.60 \mathrm{e} \pm 6.2$ \\
\hline CRA & $161.55 \mathrm{~d} \pm 26$ \\
\hline $\mathrm{N}$ & $247.15 \mathrm{~b} \pm 24.3$ \\
\hline $\mathrm{CB}$ & $83.65 \mathrm{e} \pm 4.9$ \\
\hline $\mathrm{NR}$ & $267.05 \mathrm{a} \pm 30.7$ \\
\hline CRB & $215.55 \mathrm{c} \pm 27.8$ \\
\hline
\end{tabular}

** indicate $\mathrm{P}<0.01$. Means followed by a common letter are not significantly different at the $1 \%$ level by DMRT.

- Where CA: given TAA for 6 weeks; CRA: given TAA and treated with Romiplostim for 6 weeks; N: Normal control injected with saline solution for 6 weeks; CB: given TAA for 6 weeks; NR: Normal treated with Romiplostim; CRB:given TAA and treated with Romiplostim for 8 weeks

- $\quad$ Mean \pm Standard deviations

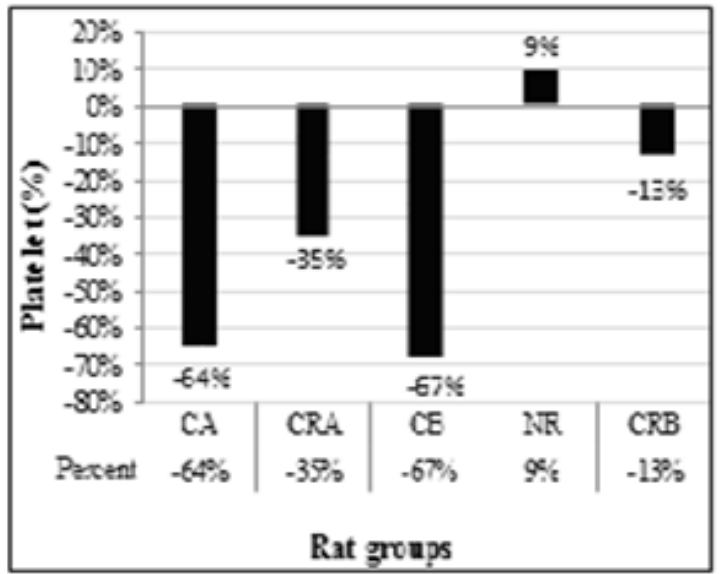

Figure (1): Percentage of platelet for different rat groups compared to $(N)$ normal control group

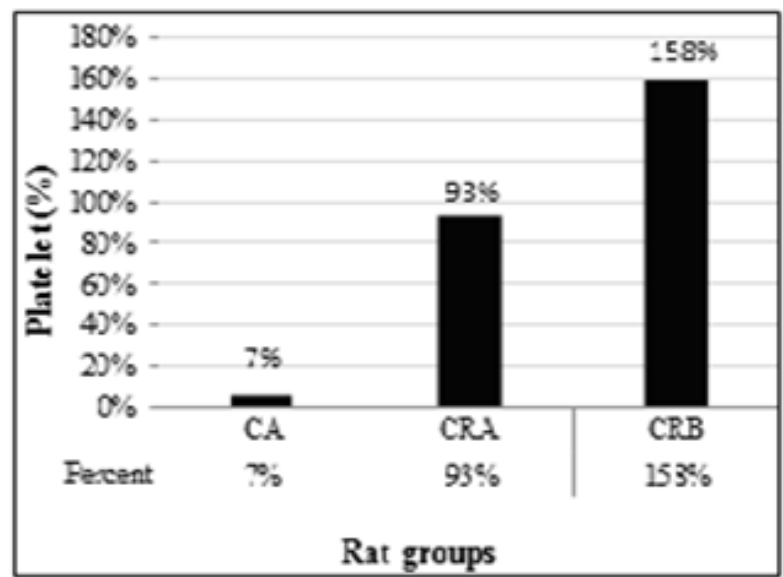

Figure (2): Percentage of platelet for CA, CRA and CRB groups compared to (CB) group 
B. Effect of Romiplostim on ALT, AST and ALP levels in different rat groups:

The greatest ALT was in the CRB group (75.2), with an insignificant difference with groups CB group (74.7), CRA (71.85) and CA (70.8). The lowest ALT value was in NR (26.50) and N (25.4) groups, whereas statistically par (Table 2). There was no significant effect between the four groups CRB, CB, CRA, and CA groups $(226.15,226.1,218.9$, and 217.75), respectively, in AST. The two groups $\mathrm{N}$ and NR, gave the lowest AST values with an insignificant difference (97.35 and 99.6), respectively (Table 2).

The ALP in the CRB group gave the highest value (177.95). The difference in the ALP of the CRB, CB, CRA and CA groups were found to be similar. The mean ALP was lower in the two groups $\mathrm{N}$ and NR with an insignificant difference (Table 2). Figure (3) showed the percentage of ALT, AST, and ALP for different rat groups compare to $(\mathrm{N})$ normal control group. The percentage of ALT increased for all groups compared to the $\mathrm{N}$ group, the group CRB gave (197\%), followed by CB (195\%), CRA (183\%), and CA (179\%) (Figure 3).

For AST (\%) in Figure 3, the highest percentage was CRB and CRA (133\%) compared with the $\mathrm{N}$ control group, whereas the lowest NR group (3\%). There was an increase in the ALP of rats in all groups than the $\mathrm{N}$ control group, with percentage changes $102 \%, 100 \%, 92 \%$, $90 \%$, and $2 \% \%$ for groups CRB, CB, CRA, CA, and NR, respectively (Figure 3).

Table (2): Effect of Romiplostim and on ALT, AST and ALP of different rat groups.

\begin{tabular}{|c|c|c|c|}
\hline Groups & ALT & AST & ALP \\
\hline CA & $70.8 \mathrm{a} \pm 7.61$ & $217.75 \mathrm{a} \pm 20.8$ & $167 \mathrm{a} \pm 19.84$ \\
\hline CRA & $71.85 \mathrm{a} \pm 7.49$ & $218.90 \mathrm{a} \pm 23.2$ & $168.8 \mathrm{a} \pm 15.41$ \\
\hline N & $25.4 \mathrm{~b} \pm 4.85$ & $97.35 \mathrm{~b} \pm 10.4$ & $87.95 \mathrm{~b} \pm 18.29$ \\
\hline CB & $74.7 \mathrm{a} \pm 7.73$ & $226.10 \mathrm{a} \pm 19.8$ & $175.65 \mathrm{a} \pm 17.95$ \\
\hline NR & $26.5 \mathrm{~b} \pm 6.25$ & $99.60 \mathrm{~b} \pm 11.8$ & $89.3 \mathrm{~b} \pm 15.19$ \\
\hline CRB & $75.2 \mathrm{a} \pm 6.72$ & $226.15 \mathrm{a} \pm 17.8$ & $177.95 \mathrm{a} \pm 15.82$ \\
\hline$P$. & 0.00 & 0.00 & 0.00 \\
\hline
\end{tabular}

**indicate $\mathrm{P}<0.01$. Means followed by a common letter are not significantly different at the $1 \%$ level by DMRT.

- Where CA: given TAA for 6 weeks; CRA: given TAA and treated with Romiplostim for 6 weeks; N: Normal control injected with saline solution for 6 weeks; CB: given TAA for 6 weeks; NR: Normal treated with Romiplostim; CRB:given TAA and treated with Romiplostim for 8 weeks

- $\quad$ Mean \pm Standard deviations 


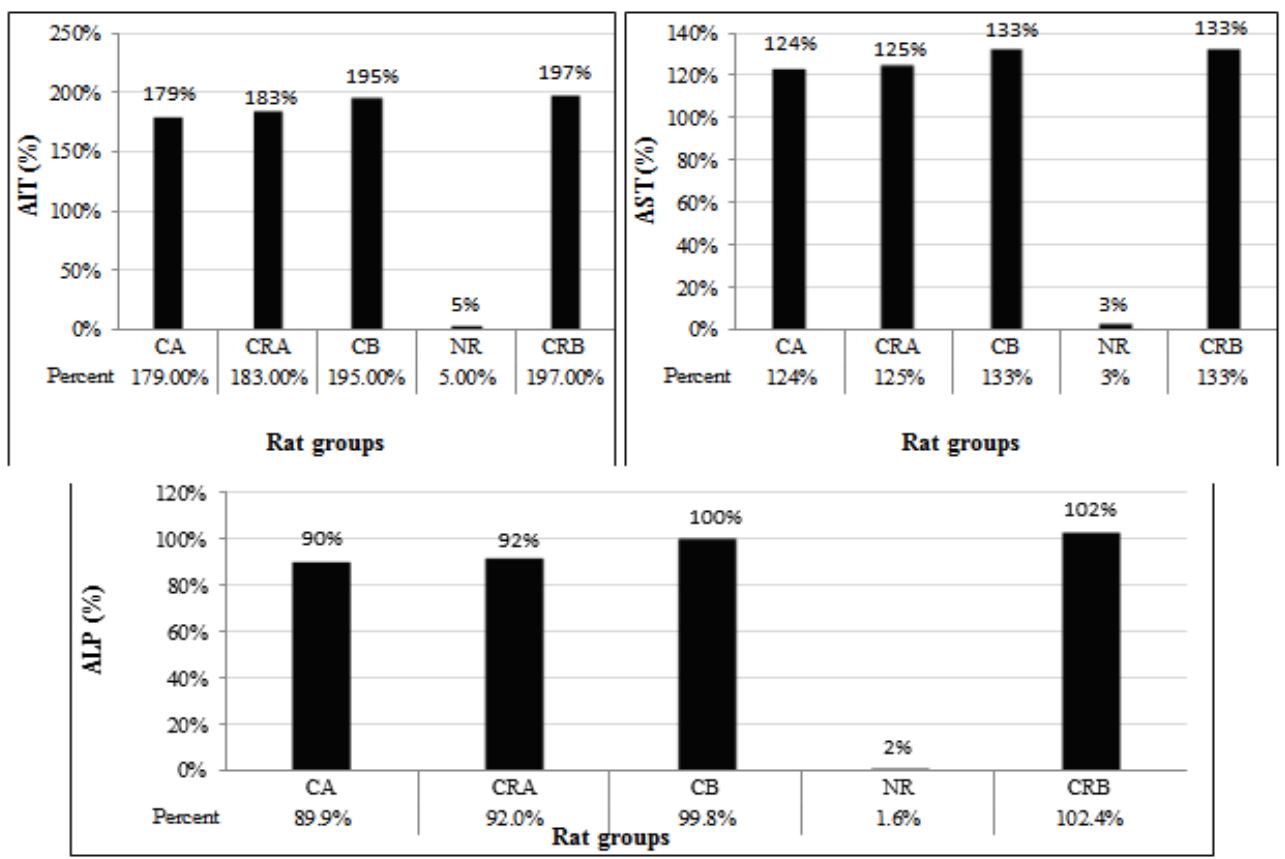

Figure (3): Percentage of ALT, AST and ALP for different rat groups compare to (N) normal control group

C. Effect of Romiplostim on total protein, albumin, total bilirubin, and direct bilirubin in different rat groups:

The total protein and albumin were significantly decreased in CA, CRA, CB, and CRB groups compared with $\mathrm{N}$ control and NR groups. The highest total protein and albumin values were the two groups, $\mathrm{N}$ control, and NR (Table 3).

For total bilirubin, the $\mathrm{CB}$ group gave the greatest value (1.37), which is an insignificant difference from CA and CRB groups. The two groups $\mathrm{N}$ and $\mathrm{NR}$ gave the lowest total bilirubin values with an insignificant difference (0.37 and 0.34), respectively (Table 3 ).

The direct bilirubin was significantly increased in $\mathrm{CA}, \mathrm{CRA}, \mathrm{CB}$, and $\mathrm{CRB}$ groups compared to $\mathrm{N}$ control and $\mathrm{NR}$ groups. The lowest direct bilirubin values were the two groups, $\mathrm{N}$ control and NR (Table 3).

Figure (4) showed the percentage of total protein, albumin, total bilirubin, and direct bilirubin for different rat groups compare to $(\mathrm{N})$ normal control group.
The percentage of total protein and albumin decreased for all groups compared to the $\mathrm{N}$ group. The group CRB and CRA gave the same reduction $(-39 \%)$, followed by CA $(-37 \%)$ and $\mathrm{CB}(-36 \%)$ for the total protein (Fig.4). The reduction of albumin was $(-52.8 \%)$ in CRB group, ($49.6 \%)$ for $\mathrm{CB},(-49.1 \%)$ for CRA, ($47.3 \%)$ for $\mathrm{CA}$ and $(-2 \%)$ for NR compare to $\mathrm{N}$ normal group (Figure 4).

There was an increase in the total bilirubin of rats in $\mathrm{CB}, \mathrm{CA}, \mathrm{CRB}$, and CRA than the $\mathrm{N}$ control group, with percentage changes $268 \%, 243 \%, 236 \%$, and $222 \%$, respectively (Figure 2 ). The total bilirubin reduction in NR compared to the $\mathrm{N}$ control group was $-10 \%$ (Figure 4).

There was an increase in the direct bilirubin and of rats in $\mathrm{CB}, \mathrm{CRB}, \mathrm{CA}$, and CRA than the $\mathrm{N}$ control group, with percentage changes $389 \%, 379 \%, 349 \%$, and $329 \%$, respectively (Figure 2). The direct bilirubin reduction in NR compared to the $\mathrm{N}$ control group was $-10 \%$ (Figure 4). 
Table (3): Effect of Romiplostim on total protein, albumin, total bilirubin, and direct bilirubin in different rat groups

\begin{tabular}{|c|c|c|c|c|}
\hline Groups & Total protein & Albumin & Total bilirubin & Direct bilirubin \\
\hline CA & $2.26 \mathrm{~b} \pm 0.47$ & $1.06 \mathrm{~b} \pm 0.32$ & $1.27 \mathrm{ab} \pm 0.24$ & $0.444 \mathrm{a} \pm 0.1$ \\
\hline CRA & $2.1825 \mathrm{~b} \pm 0.41$ & $1.03 \mathrm{~b} \pm 0.29$ & $1.19 \mathrm{~b} \pm 0.26$ & $0.425 \mathrm{a} \pm 0.14$ \\
\hline N & $3.54 \mathrm{a} \pm 0.76$ & $2.01 \mathrm{a} \pm 0.45$ & $0.375 \mathrm{c} \pm 0.07$ & $0.099 \mathrm{~b} \pm 0.05$ \\
\hline CB & $2.3 \mathrm{~b} \pm 0.59$ & $1.02 \mathrm{~b} \pm 0.37$ & $1.37 \mathrm{a} \pm 0.27$ & $0.484 \mathrm{a} \pm 0.16$ \\
\hline NR & $3.51 \mathrm{a} \pm 0.72$ & $1.97 \mathrm{a} \pm 0.41$ & $0.34 \mathrm{c} \pm 0.07$ & $0.09 \mathrm{~b} \pm 0.05$ \\
\hline CRB & $2.17 \mathrm{~b} \pm 0.48$ & $0.95 \mathrm{~b} \pm 0.33$ & $1.2 \mathrm{ab} \pm 0.16$ & $0.474 \mathrm{a} \pm 0.18$ \\
\hline$P$. & $* * 0.00$ & $* * 0.00$ & $* * 0.00$ & $* * 0.00$ \\
\hline
\end{tabular}

** indicate $\mathrm{P}<0.01$. Means followed by a common letter are not significantly different at the $1 \%$ level by DMRT.

- Where CA: given TAA for 6 weeks; CRA: given TAA and treated with Romiplostim for 6 weeks; N: Normal control injected with saline solution for 6 weeks; CB: given TAA for 6 weeks; NR: Normal treated with Romiplostim; CRB:given TAA and treated with Romiplostim for 8 weeks

- $\quad$ Mean \pm Standard deviations
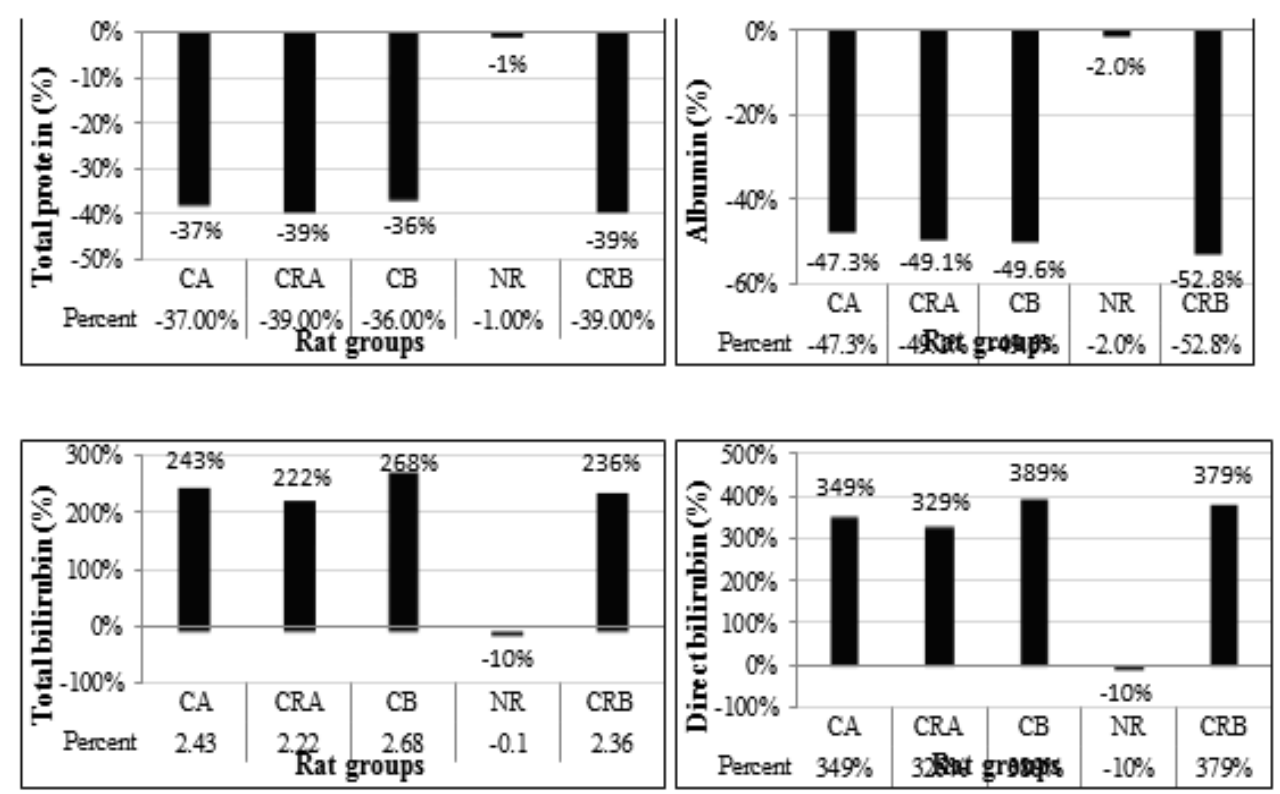

Figure (4): Percentage of total protein, albumin, total bilirubin, and direct bilirubin for different rat groups compare to $(\mathrm{N})$ normal control group

\section{Effect of Romiplostim on Gamma Glutmlytranspeptidase level in different rat groups: \\ The greatest \\ Gamma}

Glutmlytranspeptidase was the CA group (98.7), with an insignificant difference with the CB group (96.8), CRB (96.4), and CRA (92.55). The lowest Gamma Glutmlytranspeptidase value was NR
(46.15) and $\mathrm{N}$ (44.75) groups, whereas statistically par (Table 4).

The percentage of Gamma Glutmlytranspeptidase increased for all groups compared to the $\mathrm{N}$ group. The group CA gave (121\%), followed by CB (117\%), CRB (116\%), CRA (107\%) and NR (4\%) for the Gamma Glutmlytranspeptidase (Figure 5). 
Table (4): Effect of Romiplostim on Gamma Glutmlytranspeptidase level in different rat groups

\begin{tabular}{|c|c|}
\hline Groups & Gamma Glutmlytranspeptidase \\
\hline CA & $98.7 \mathrm{a} \pm 11.04$ \\
\hline CRA & $92.55 \mathrm{a} \pm 9.92$ \\
\hline $\mathrm{N}$ & $44.75 \mathrm{~b} \pm 6.54$ \\
\hline $\mathrm{CB}$ & $96.8 \mathrm{a} \pm 11.82$ \\
\hline $\mathrm{NR}$ & $46.15 \mathrm{~b} \pm 8.62$ \\
\hline $\mathrm{CRB}$ & $96.4 \mathrm{a} \pm 9.9$ \\
\hline
\end{tabular}

** indicate $\mathrm{P}<0.01$. Means followed by a common letter are not significantly different at the $1 \%$ level by DMRT.

- Where CA: given TAA for 6 weeks; CRA: given TAA and treated with Romiplostim for 6 weeks; N: Normal control injected with saline solution for 6 weeks; CB: given TAA for 6 weeks; NR: Normal treated with Romiplostim; CRB:given TAA and treated with Romiplostim for 8 weeks

- $\quad$ Mean \pm Standard deviations

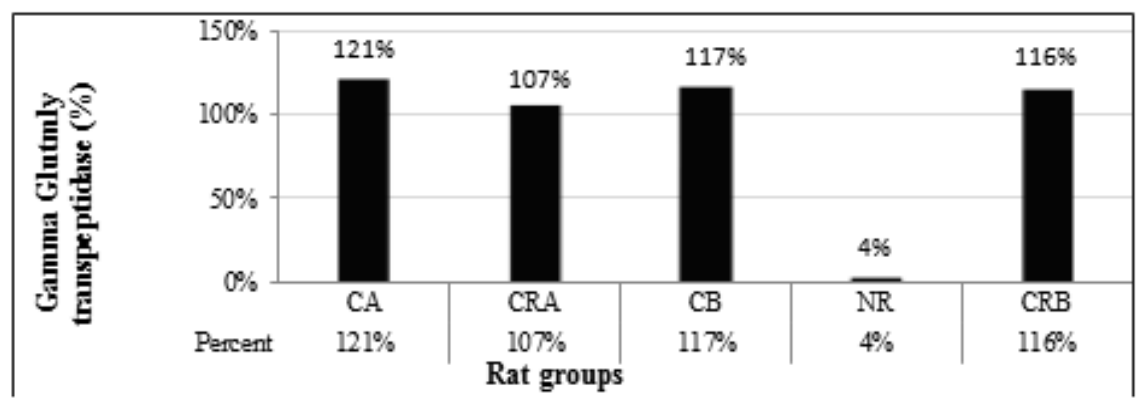

Figure (5): Percentage of Gamma Glutmlytranspeptidase for different rat groups compared to $(\mathbf{N})$ normal control group

\section{E. Histopathology:}

Histopathological examination of liver sections from $\mathrm{N}$ and $\mathrm{NR}$ groups showed normal hepatocellular architecture while histopathological examination of liver sections of rats exposed to TAA for six weeks CA and CRA groups showed a structural damage with the increased extracellular matrix collagen. In addition, histopathological examination of liver sections from rats intoxicated with TAA for eight weeks $\mathrm{CB}$ and $\mathrm{CRB}$ groups showed extensive alterations of tissue architecture and advanced fibrosis with increases of extracellular matrix collagen content. In addition Romiplostim injection showed insignificant changes in histopathological examination of liver sections of different rat groups' Figure (6). 


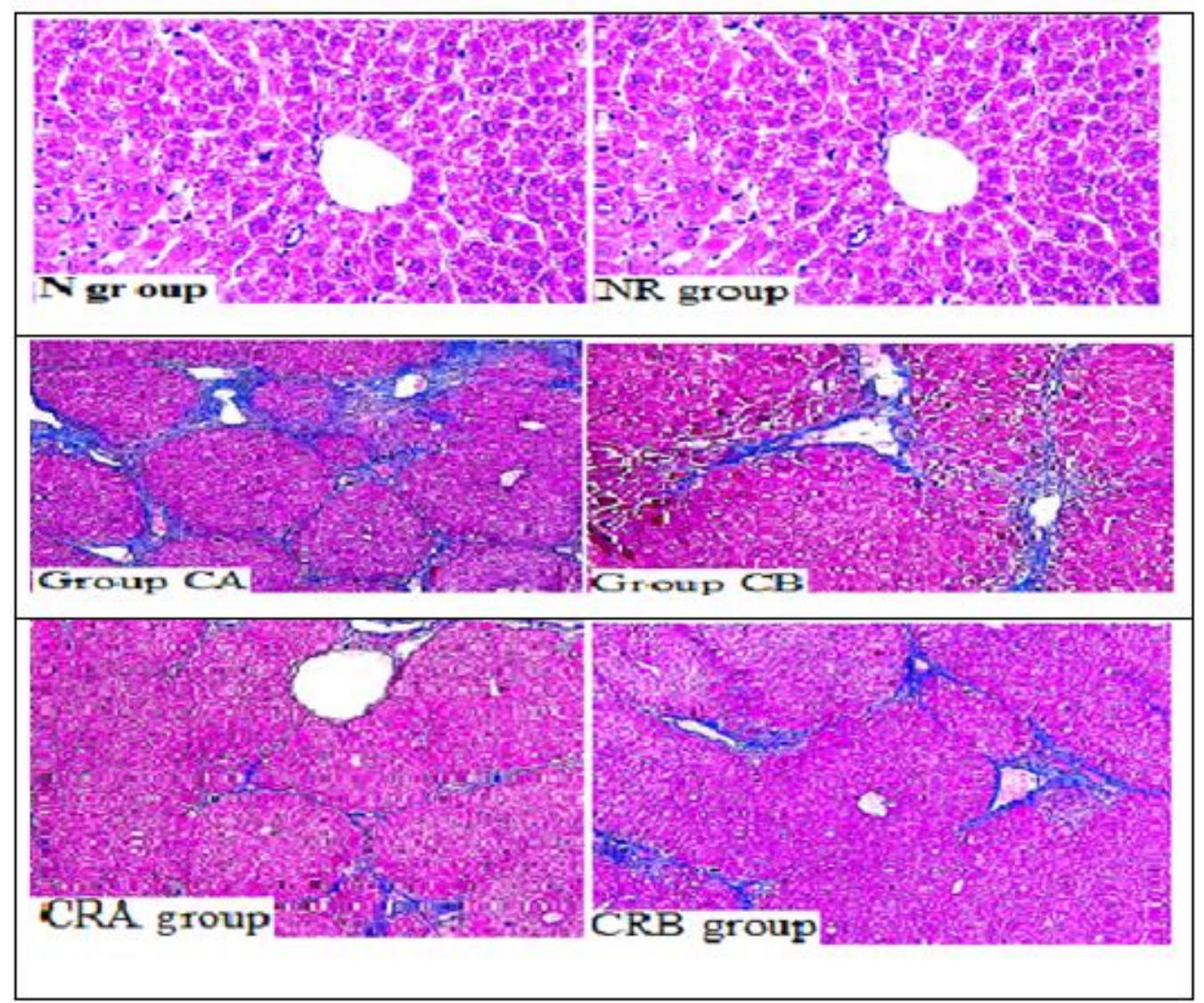

Figure(6): Where CA: given TAA for 6 weeks; CRA: given TAA and treated with Romiplostim for 6 weeks; N: Normal control injected with saline solution for 6 weeks; CB: given TAA for 6 weeks; NR: Normal treated with Romiplostim; CRB:given TAA and treated with Romiplostim for 8 weeks $(\mathbf{H} \& \mathbf{E} \times \mathbf{4 0 0})$.

\section{DISCUSSION}

Liver or hepatic diseases resulting from liver damage is a global problem. Among hepatic diseases, cirrhosis is an important and common cause of human mortality in many countries. Most liver pathologies ended by cirrhosis, even its etiologies (Galisteo et al., 2014). Thrombocytopenia is frequently present in the patients with CLD (Schuppan and Kim, 2013).

Thrombocytopenia is a common hematological problem that is frequently chronic. While many patients with ITP, chronic liver disease or primary bone marrow disorders may live without excessive bleeding or bruising at platelet counts far below the normal range. Bleeding risk increases greatly if challenged by surgical procedures. Surgeons are therefore often hesitant to operate on these patients out of concern for bleeding complications. Patients may also refuse needed procedures out of similar concerns. While platelet transfusions may be effective in raising the platelet count in the perioperative setting in many patients, it may not be effective in some (due to ITP or all immunization) and may refuse by others (e.g. Jehovah's Witnesses). There is clearly a need for alternatives to platelet transfusion (Hanny et al., 2018). 
Thrombopoietin (TPO) is a growth factor produced in the liver that binds to the c-Mpl receptor present on megakaryocytes and platelets. The activation of the JAK-STAT mechanism occurs after TPO binds to its receptor and results in platelets production stimulation (Kuter, 2013). The platelet count rise occurs after a latency period of 5 days and reaches a peak after 10-12 days (Deutsch and Tomer, 2013). A decreased platelet count leads to an increase of free TPO levels, which induces a higher platelet production by bone marrow megakaryocytes (Molineux, 2011).

Romiplostim is a peptide-antibody composed of a unique 14 amino acid sequence that lacks sequence homology with endogenous TPO. This decreases immunogenicity and the theoretical risk of subsequent autoantibody formation. Dimerization of the peptide sequence allows for stimulation of both binding sites located on the TPO receptor. The short circulatory half-life of the dimerized peptide is prolonged by binding to each arm of the IgG1 heavy chain. The resultant "peptibody" is protected from degradation via recycling by endothelial cells through the FcRn receptor. The peptibody is then returned to circulation, extending the half-life of romiplostim to 120-140 hours (Wang et al., 2014).

In our study thrombopoietin receptors agonist, (romiplostim) administration shows increase in number of platelet count in cirrhotic albino rats. This result was in agreement with Jemal A., (2019) who found the potential advantages of a TPO$\mathrm{R}$ agonist in the management of thrombocytopenia associated with chronic liver disease and other conditions. The interpretation of this result was studied by David et al., 2010 who demonstrated that binding and activation of the TPO receptor activates intracellular transcriptional pathways, leading to increased platelet production. These results are in agreement with Moussa and Mowafy monitored a rapid response to Romiplostim therapy in patients with chronic hepatitis $\mathrm{C}$, liver cirrhosis and thrombocytopenia secondary to $\mathrm{HCV}$ infection achieving platelet counts $70 \mathrm{x}$ 109/L (Moussa and Mowafy, 2013). On the other hand, thrombopoietin receptor agonists, such as eltrombopag and romiplostim, can increase platelet counts in thrombocytopenic patients with $\mathrm{HCV}$ related cirrhosis (Voican et al., 2012, Taylor et al., 2013 and McHutchison et al., 2017).

Further Broudy and Linstated that Romiplostim increases the platelet production, which is similar to that of eTPO (Broudy and Lin, 2014). In addition, various clinical trials in patients with chronic immune thrombocytopenic purpura have shown Romiplostim to cause a dose dependent increase in platelet count, resulting in lower rates of treatment failure, decreased the need for splenectomy and improved quality of life (Kuter et al., 2010, Bussel et al., 2016 and Kuter et al., 2018).Therefore, the development of platelet stimulatory therapy is promoted Romiplostim (Newland and Romiplostim, 2019), for example, as a Thrombopoietin receptor agonist, is a $\mathrm{Fc}$ fusion protein (also known as antibody) (Wang et al., 2014).

The correction of thrombocytopenia in CLD improves general health by correction of bleeding tendency. This 
match with many clinical case reports that shown a possible role of Romiplostim in the preparation preliver transplant or prior for invasive therapeutic procedure (Dultz et al., 2011 and Sivera et al., 2012). In addition, this improvement in the general health allows and improves effect of other medications used in the treatment of CLD. This matches with the study that shows Romiplostim allowed the treatment of hepatitis $\mathrm{C}$ in a patient coinfected with HIV (Taylor, 2013). At the same time our results shows no significant effect on the liver functions which agreed with Bussel et al., revealed that long-term Romiplostim treatment in small group of patients maintained platelet counts for over 4 years in children with ITP with good tolerability without significant hepatotoxicity (Bussel et al., 2015). In addition, this agreed with the study that shows Romiplostim was given to a splenectomised patient with immune thrombocytopenic purpura before PEGIFN/ribavirin treatment; the antiviral treatment started at a value of $65 \times 103$ platelets/mm3 and led to an early virological response followed by a sustained virological response; in this case, romiplostim was effective and safe (Buccoliero, 2014).

In addition, a severe thrombocytopenia produced during the antiviral treatment of two HCV-related cirrhosis patients was successfully treated with romiplostim (with a platelet count >50x103/mm3), which allowed continuation and completion of the IFN protocol without dose reduction; both patients obtained a sustained virological response (Voican, 2012).
As regard liver functions, the result of present study showed that the greatest ALT was in the CRB group and the lowest ALT value was in NR .while the ALP in the CRB group gave the highest value. This result was in agreement with Sharma, 2014 who stated that Eltrombopag (TPO) has insignificant role in treatment of liver disease associated with thrombocytopenia.

As regards, the total protein and albumin level in the present work, results revealed that total protein and albumin level were significantly decreased in CA, CRA, CB, and CRB groups compared with $\mathrm{N}$ control and NR groups, while the highest total protein and albumin values were in the two groups, $\mathrm{N}$ control, and NR.

This result also was compatible with Poordad et al. (2014) who stated that Avatrombopag is a promising agent that could probably be used for thrombocytopenic patients with chronic liver disease.

This result was incompatible with Shyam and Andrew (2016) who reported that the use of thrombopoietinrecept or agonists for correction of thrombocytopenia prior to elective procedures in chronic liver diseases has insignificant value on liver protein.

As regards Gamma Glutmlytranspeptidase level and its relation with Romiplostim in the present work, the obtained data showed that the greatest Gamma Glutmlytranspeptidase was in the CA group with an insignificant difference with the $\mathrm{CB}$ group, CRB, and CRA, while the lowest Gamma Glutmlytranspeptidase value was in NR and $\mathrm{N}$ groups. 
Hans et al; 2010 studied the use of thrombopoietic agents for the thrombocytopenia and found that romiplostim administration increase Gamma Glutmlytranspeptidase level in chronic liver disease.

\section{CONCLUSION}

Romiplostim administration increase platelet count in cirrhotic albino rats. This effect happened by binding and activation of the TPO receptor, it activates intracellular transcriptional pathways, leading to increased platelet production this occurs without affection of liver functions so it can be used to prevent bleeding in cirrhotic patients and improving their general health. We can also use romiplostim in different conditions of thrombocytopenia but it must be tested in other conditions of thrombocytopenia before use to shows its harmful effects on different patients.

\section{REFERENCES}

1. Afdhal, N., McHutchison, J., Brown, R., Jacobson, I., Manns, M., Poordad, F., and Esteban, R. (2012): Thrombocytopenia associated with chronic liver disease. Journal of hepatology, 48(6): 1000-1007.

2. Bancroft $D$, Stevens $A$ and Turner $R$ (2019): Theory and practice of histological techniques. Advances in Bioscience and Biotechnology, Vol.3 No.4A.

3. Basser $\mathbf{R}$ (2020): The impact of thrombopoietin on clinical practice. Curr Pharm Des., 8 (5):369-377.

4. Broudy VC and Lin NL (2014): AMG531 stimulates megakaryopoiesis in vitro by binding to Mpl. Cytokine, 25: 52-60.

5. Buccoliero G (2014): Romiplostim for severe thrombocytopenia in the treatment of chronic hepatitis $\mathrm{C}$ virus infection: a new option for clinicians? New Microbiol., 37(1):97-101
6. Bussel JB, Kuter DJ, George JN, McMillan R, Aledort LM, Conklin GT, Lichtin AE, Lyons RM, Nieva J and Wasser JS (2016): AMG 531, a thrombopoiesis-stimulating protein, for chronic ITP. New England Journal of Medicine, 355(16): 1672-1681.

7. Bussel, J. B., Hsieh, L., Buchanan, G. R., Stine, K., Kalpatthi, R., Gnarra, D. J., HO, R. H., NIE, K., and EISEN, M. (2015): Long-Term Use of the ThrombopoietinMimetic Romiplostim in Children With Severe Chronic Immune Thrombo-cytopenia (ITP). Pediatric Blood Cancer, 62: 208-13.

8. Cooper, N., Terrinoni, I., and Newland, A. (2012): The efficacy and safety of romiplostim in adult patients with chronic immune thrombocytopenia. Therapeutic advances in hematology, 3(5), 291-298.

9. David J. Phil D. and Terry B. (2010): Thrombopoietin and Platelet Production in Chronic Immune Thrombocytopenia, Hematol OncolClin North Am. 23(6): 1193-1211.

10. Deutsch VR and TomerA (2013): Advances in megakaryocytopoiesis and thrombopoiesis: from bench to bedside. $\mathrm{Br} \mathrm{J}$ Haematol, 161(6):778-93.

11. Dultz, G., Kronenberger, B. Azizi, A. Mihm, U. Vogl J. and Sarrazin, U. (2011): Portal vein thrombosis as complication of romiplostim treatment in a cirrhotic patient with hepatitis C-associated immune thrombocytopenic purpura. J. Hepatol, 55:229-232.

12. Ehrlich, L. A., Kwitkowski, V. E., Reaman, G., Ko, C. W., Nie, L., Pazdur, R., and Farrell, A. T. (2017): US Food and Drug Administration approval summary: Eltrombopag for the treatment of pediatric patients with chronic immune (idiopathic) thrombocytopenia. Pediatric Blood and Cancer, 21(8), 57-65.

13. Galisteo, M., Sua' rez, A., Montilla, M.P., Torres, M.I., Gil, A.and Navarro, M.C., (2014): Protective effects of Rosmarinus tomentosus ethanol extract on thioacetamideinduced liver cirrhosis in rats. Phytomedicine, 13, $101-108$. 
14. Gangireddy, V. G. R., Kanneganti, P. C., Sridhar, S., Talla, S., and Coleman, T. (2014): Management of thrombocytopenia in advanced liver disease. Canadian Journal of Gastroenterology and Hepatology, 28(10), 558-564. $(5,7)$

15. Hanny A, Ariela L. Marshall, Katayoon G, David J and Kuter (2018): Romiplostim for the management of perioperative thrombocytopenia. British journal of hematology, volume 182 issue 116.

16. Hans L, John T and Mc Hutchison (2010): Use of thrombopoietic agents for the thrombocytopenia of liver disease. Semin Hematol, 47(3):266-73.

17. Jemal A, (2019): Current Advance in Thrombopoietin Receptor Agonists in the Management of Thrombocytopenia Associated With Chronic Liver Disease, Clin Med Insights Blood Disord. 17, 11: 17.

18. Kuter DJ (2013): The biology of thrombopoietin and thrombopoietin receptor agonists. Int J Hematol., 98 (1):10-23.

19. Kuter DJ, Bussel JB, Lyons RM, Pullarkat V, Gernsheimer TB, Senecal FM, Aledort LM, George JN, Kessler CM and Sanz MA (2018): Efficacy of romiplostim in patients with chronic immune thrombocytopenic purpura: a double-blind randomised controlled trial. The Lancet, 371 (9610): 395-403.

20. Kuter DJ, Rummel M, Boccia R, Macik BG, Pabinger I, Selleslag D, Rodeghiero F, Chong BH, Wang $X$ and Berger DP (2010): Romiplostim or standard of care in patients with immune thrombocytopenia. New England Journal of Medicine,363(20): 18891899.

21. Liu CC, Jewett MC, Chin JW, Voigt CA and Liu CC, (2018): Nat ChemBiol Jan, 16; 14 (2):103-106.

22. Lubran, M. M. (2019): The measurement of total serum proteins by the Biuret method. Annals of Clinical and Laboratory Science, 8(2), 106-110.

23. Mc Hutchison JG, Dusheiko G, Shiffman ML et al (2017): Eltrombopag for thrombocytopenia in patients with cirrhosis associated with hepatitis C. N Engl J Med, 357:2227-2236.

24. Mitchell, O., Feldman, D. M., Diakow, M., and Sigal, S. H. (2016): The pathophysiology of thrombocytopenia in chronic liver disease. Hepatic medicine: evidence and research, 8, 39. $(1,4)$.

25. Molineux G (2011): The development of romiplostim for patients with immune thrombocytopenia. Ann N Y Acad Sci., 1222(1):55-63.

26. Moussa, M.M. and Mowafy, N. (2013): Preoperative use of Romiplostim in thrombocytopenic patients with chronic hepatitis $\mathrm{C}$ and liver cirrhosis. Journal of Gastroenterology and Hepatology, 28: 335341.

27. Newland A, (2019): A breakthrough treatment for the management of immune thrombocytopenic purpura. Eur J HaematolSuppl, 71: 20-25.

28. Qamar AA, Grace ND and Groszmann RJ (2009): Portal Hypertension Collaborative Group Incidence, prevalence, and clinical significance of abnormal hematologic indices in compensated cirrhosis. ClinGastroenterol Hepatol., 7:689-95.

29. Poordad F, Hezode C, Trinh R, Kowdley KV, Zeuzem S and Agarwal K. (2014): ABT-450/r-ombitasvir and dasabuvir with ribavirin for hepatitis $\mathrm{C}$ with cirrhosis $\mathrm{N}$ Engl J Med.; 370(21):1973-1982.

30. Qureshi, K., Patel, S., and Meillier, A. (2016): The Use of Thrombopoietin Receptor Agonists for Correction of Thrombocytopenia prior to Elective Procedures in Chronic Liver Diseases: Review of Current Evidence. International journal of hepatology, 23(7): 5-9.

31. Reitman S., Frankel S., Am (2014): GTP Colorimetric test Clin. Pathol, 28:56-63.

32. Said, E., Said, S. A., Gameil, N. M., and Ammar, E. M. (2013): Modulation of thioacetamide-induced liver fibrosis/cirrhosis by sildenafil treatment. Canadian journal of Physiology and Pharmacology, 91(12), 10551063. 
33. Saleh, M. N., Bussel, J. B., Cheng, G., Meyer, O., Bailey, C. K., Arning, M., and Brainsky, A. (2013): Safety and efficacy of eltrombopag for treatment of chronic immune thrombocytopenia: results of the long-term, open-label extend study. Blood, 121(3), 537 545.

34. Schuppan, D., and Kim, Y.O., (2013): Evolving therapies for liver fibrosis. J. Clin. Invest, 123, 1887-1901.

35. Sharma, (2014): Use of eltrombopag in thrombocytopenia of liver disease. World Journal of Pharmacology 3(4):186-192.

36. Shyam and Andrew (2016): The Use of Thrombopoietin Receptor Agonists for Correction of Thrombocytopenia prior to Elective Procedures in Chronic Liver Diseases. International Journal of Hepatology, 43, 130-145.

37. Sivera, P., Ruella, M. Gueli, A. Hu, H. Wade M. And Tarella. C. (2012): Use of the novel Thrombopoietin receptor-agonist romiplostim, in combination with steroids and immunoglobulins for the increase of platelets prior to splenectomy, in refractory immune thrombocytopenia: a case report. Blood Coagul. Fibrinolysis, 23:331-334.

38. Szasz G (2019): A kinetic photometric method for serum gamma- glutamyltranspeptidase. ClinChem Feb, 15 (2):124-36.

39. Taylor $\mathbf{N}$ (2013): Use of romiplostim allows for hepatitis $\mathrm{C}$ therapy in a $\mathrm{HIV} / \mathrm{HCV}$ coinfected patient. Ann Hematol., 92(7):10012.

40. Taylor N, Melchardt $\mathbf{T}$ and Grundbichler $M$ (2013): Use of romiplostim allows for hepatitis $\mathrm{C}$ therapy in a HIV/HCV coinfected patient. Ann Hematol, 92:1001-1002.

41. Vang J, Simert G, Hansson JA, Thylen U and Bengmark TS (2019): Results of a modified distal spleno-renal shunt for portal hypertension. Ann Surg., 185:224-8.

42. Voican CS (2012): Successful antiviral therapy for hepatitis $\mathrm{C}$ virus-induced cirrhosis after an increase in the platelet count with romiplostim: two case reports. Eur J Gastroenterol Hepatol., 24(12): 1455-8.

43. Voican CS, Naveau $S$ and Perlemuter G (2012): Successful antiviral therapy for hepatitis $\mathrm{C}$ virus-induced cirrhosis after an increase in the platelet count with romiplostim: two case reports. Eur J Gastroenterol Hepatol, 24:1455-1458.

44. Wang B, Nichol JL and Sullivan JT (2014): Pharmacodynamics and pharmacokinetics of AMG 531, a novel thrombopoietin receptor ligand. Clin Pharmacol Ther, 76: 628-638. 


\section{تاثثير منبهات مستقبلات الهرمون المحفز لانتاج الصفائح}

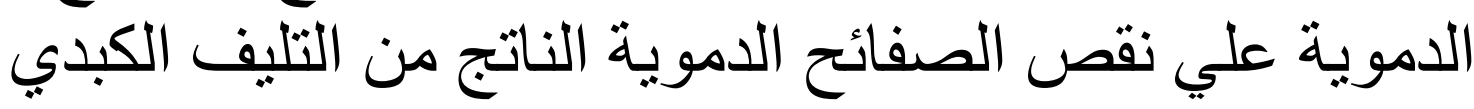

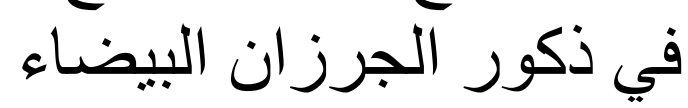

احمد السيد نور الاين1، احمد محمد طه2، احمد محمود محمد جاد الله1، عبد المجيد

\section{منصور 1}

قسم الفسيولوجى، كلية الطب جامعة الأزهر بأسيوط قسم الفسيولوجى، كلية الطب جامعة بورسعيد

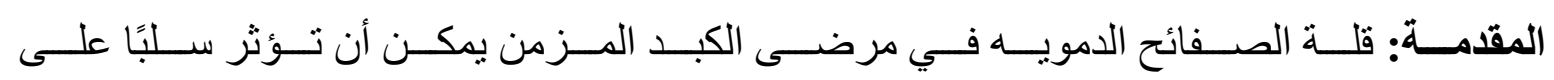

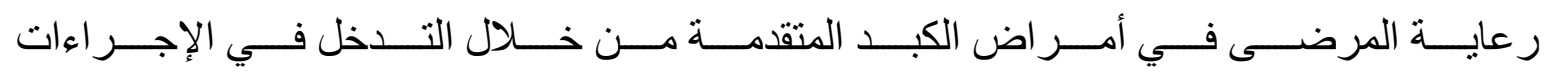

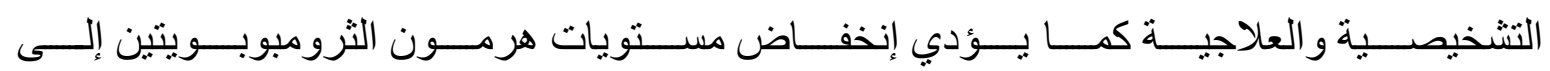

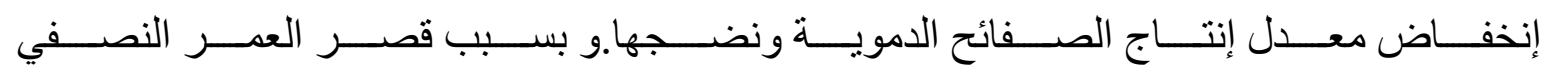

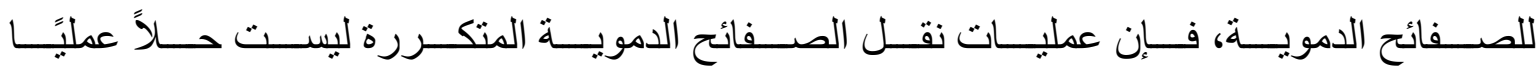
لنقص الصفيحات.

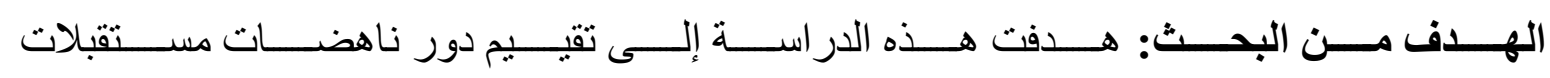
الثرومبوبويتين في علاج قلة الصفائح في مرضى الكبد المزمن.

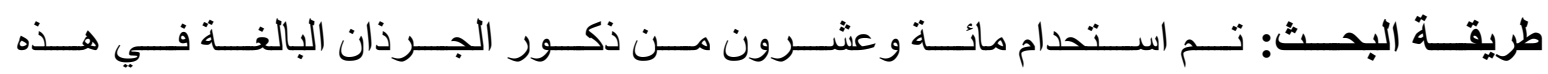

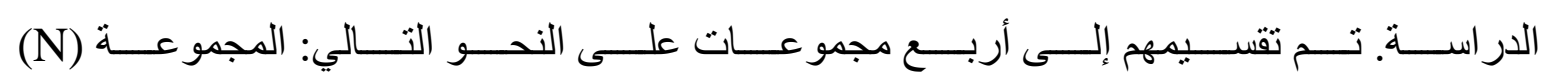

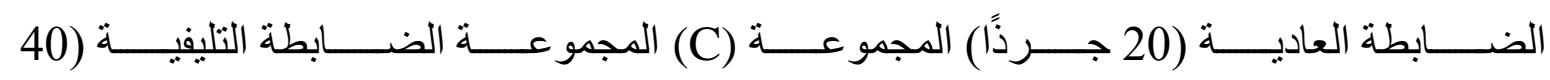

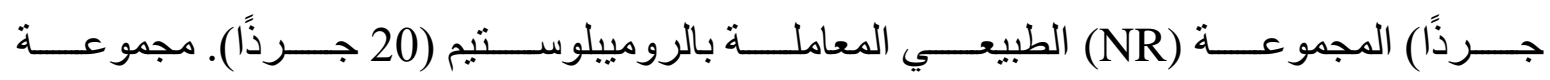

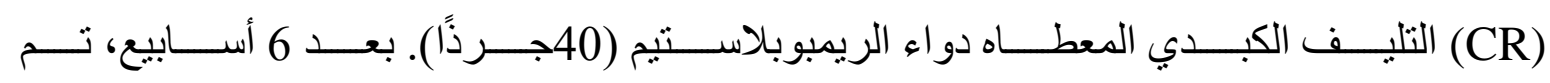

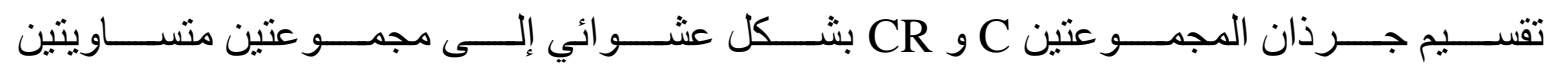

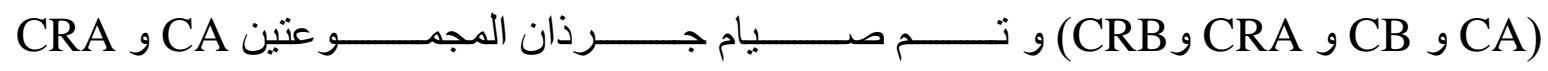

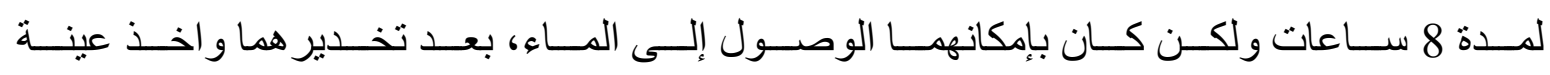

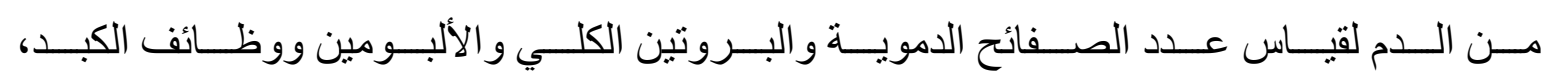

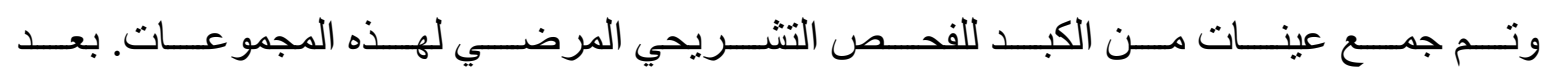

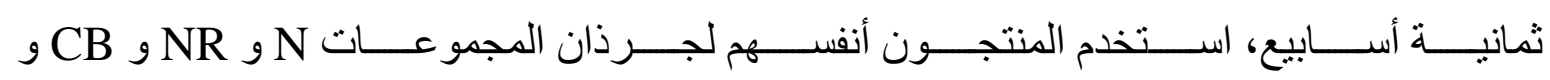




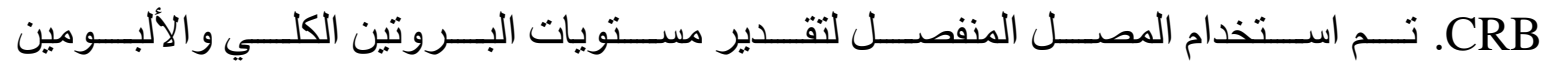
ووظائف الكبد وتم فحص جميع أقسام الكبد باستخدام المجهر الضوئي.

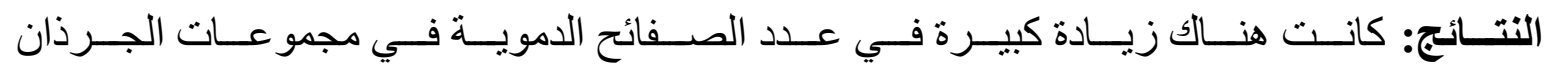

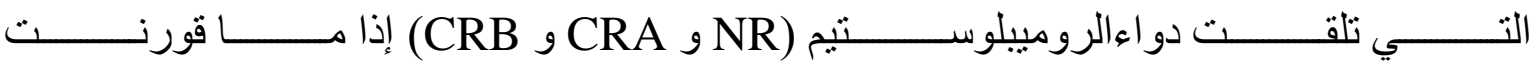

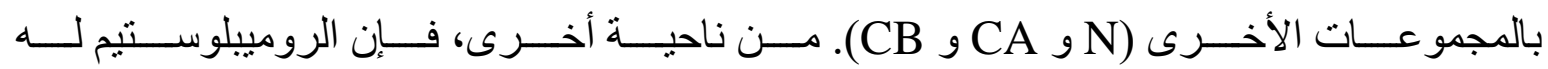

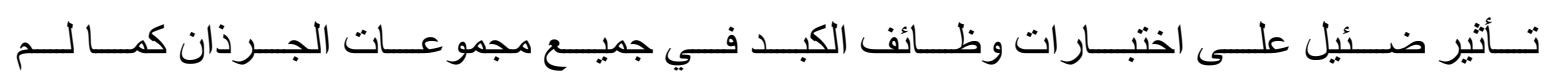

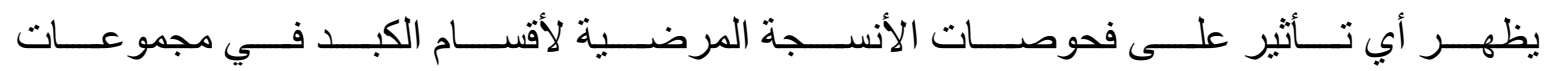
الجرذان المختلفة (NR و CRA و CRB (CRB).

الاســتنتاج: إعطــاء الرومييلوسـتيم ادي الــي زيــادة عــد الصــفائح الدمويــة فــي الجــرذان البيضاء التليفية.

الكلمات الدالة: ثرومبوبويتين، رومبلوستيم، تليف الكبد، قلة الصفائح الدموية. 